Mid-American Review of Sociology

Zimmerman, Don H., and D. Lawrence Wieder

1970 "Ethnomethodology and the Problem of Order: Comment on Denzin." In J. Douglas (ed.), Understanding Everyday Life. Chicago, Ill.: Aldine.

Zimmerman, Don H., and Melvin Pollner

1970 “The Everyday World as a Phenomenon." In J. Douglas (ed.), Understanding Everyday Life. Chicago, Ill.: Aldine.

\section{MARCUSE AND THE PROBLEM OF INSTRUMENTAL RATIONALITY}

Parviz Piran

University of Kansas

Mid-American Review of Sociology, 1977, Vol. 2, No. 2:19-28

This paper examines Marcuse's approach to the major problem of capitalism-the domination of subjective reason over objective reason. It is argued that Marcuse's approach to this problem differs from the approach of Critical Theory. It is further argued that there is a contradiction in Marcuse's argument, namely, the contradiction between revolutionary change and the change suggested by Marcuse's aesthetic perspective.

Herbert Marcuse, along with other critical theorists, has found the major problem of capitalism, especially in its modern stage, manifested in the way that instrumental rationality has been employed. For him, the present stage of history can be singled out as a period in which the process of rationalization has become entirely one-sided and limited only to the rationality of methods and means. The reason for such one-sidedness and limitation, according to Marcuse and the Critical School, can be found in the domination of "subjective reason" over "objective reason". Rationality, which in its totality aims at the emancipation of man, has turned out to be the main source of alienation and self-imprisonment for mankind. The manifestation of one-sided rationality (instrumental rationality) and alienated man can be seen in the dialectical relationships among man, society, and nature.

In order to explain the dialectical relationships among man, society, and nature in the contemporary system of domination, Marcuse argues that a new approach to social phenomenon must be adopted because the traditional perspectives, including the instrumental perspective, have not been able to predict the developments of the present stage of history. According to Marcuse, a new perspective is needed to understand and guide the 
revolutionary change which must occur within the present system of domination and the relationship of man to nature. The new perspective suggested by Marcuse is the aesthetic perspective, which emancipates man by translating subjective reason into objective form. Marcuse's aesthetic perspective does not reject instrumental rationality, but rather complements and enhances it.

It is the purpose of this paper to explore a contradiction in Marcuse's argument, namely, the contradiction between revolutionary change and the change suggested by Marcuse's aesthetic perspective. I will not attempt to posit Marcuse's approach wrong. Rather, I will only show a discrepancy between critical theory and Marcuse's perspective. This will involve examining: 1) the problem of the domination of subjective reason over objective reason; 2) Critical Theory's approach to this problem; and 3) Marcuse's approach to this problem and the discrepancy between Marcuse's approach and that of Critical Theory.

\section{THE DOMINATION OF SUBJECTIVE REASON OVER OBJECTIVE REASON}

For Marcuse and other critical theorists "reason was born from man's urge to dominate nature..." (Horkheimer, 1974: 176). This urge has faced a contradiction from the beginning which Horkheimer has called the "disease of reason." Despite such a disease, reason has expanded constantly, to the extent that it has touched almost all aspects of human life. Moreover; reason has become the "fundamental category of philosophical thought" (Marcuse, 1968:135), which aims to understand the essence of being. Of course, in order to understand the true essence of being, the situation, the historical context, customs, laws and existing regularities must also be taken into account.

Reason also is the ultimate base of social action or, in the Weberian sense, meaningful action. Meaningful action can be achieved by applying "the faculty of classification, inference, and deduction, no matter what the specific content-the abstract functioning of the thinking mechanism. This type of reason may be called 'subjective reason'" (Horkheimer, 1974: 3). Subjective reason is the base of instrumental rationality which is "a method-mean rationality for achieving ends, but it is not responsible for rationality of these ends themselves" (Landmann, 1976: 187).

In contrast, there exists another type of reason, which not only seeks to apply rational means to achieve ends, but also is emphatically responsible for the quality of ends themselves. This type of reason can be named "objective reason."

Great philosophical systems, such as those of Plato and Aristotle, Scholasticism, and German idealism were founded on an objective theory of reason. It is aimed at evolving a comprehensive system, or hierarchy, of all beings, including man and his aims. The degree of reasonableness of man's life could be determined according to its harmony with this totality. Its objective structure, and not just man and his purposes, was to be the measuring rod for individual thoughts and actions (Horkheimer, 1974: 4).

Man works upon nature as his "inorganic body" and through his works he should be able to realize and experience his full capacities. But self-realization and experience of man's hidden capacities through encounter with nature are only possible if a synthesis between the objective and subjective reason is accomplished. During the past and under the present circumstances, "objective reason" has become more and more alienated from "subjective reason", and the latter has entirely dominated the former. The immediate consequence of such a situation is the impossibility of self-realization through man's relationship with nature. Moreover, the domination over nature has lost its meaning and aim (the emancipation of man) and has become an end in itself. Man no more seeks his alienated potentialities through work upon nature and mastery over it; rather, his attempts are in search of mastery itself. The outcome of this situation, as Max Horkheimer has seen it, is frustration and self-estrangement which man has faced from the time he began to
overcome nature. 
The disease of reason is that reason was born from man's urge to dominate nature.... From the time when reason became the instrument for domination of human and extra-human nature by man-that is to say, from its very beginning-it has been frustrated in its own intention of discovering the truth. This is due to the very fact that it made nature a mere object, and that it failed to discover the trace of itself in such objectification, in the concept of matter and things not less than in those of gods and spirit (Horkheimer, 1974: 176).

The cause of reason's inability to trace itself through objectification in the concept of matter and things is based upon the contradiction inherent in the human condition and man's urge to dominate nature. Forms of thinking and their structures have always been conditioned by the social need of controlling nature on the one hand, and the incompetence of society in repressing the idea of something transcending the subjectivity of self-interest, to which the self could not help aspiring, on the other hand (Horkheimer, 1974).

Under such a situation, the domination of subjective reason over objective reason becomes almost inevitable. And when subjective reason, alienated from the objective type, becomes the dominant form of reason, the mastery of nature can only be possible through instrumental rationality. This point turns to be a central issue for Marcuse as well as other members of the Frankfurt School. Accordingly, their focus of attention becomes a critique of instrumental rationality, not only for presenting the irrationality of ends based on instrumental rationality, but also for introducing new perspectives which aim at overcoming the irrational ends.

\section{CRITICAL THEORY AND THE CONCEPT OF REASON}

According to Critical Theory, a synthesis between objective reason and subjective reason should and can be attained.
Accomplishment of such a synthesis will give reason a critical characteristic which can be applied for criticizing the existing reality for the sake of truth.

Criticism of existing reality is a central point for the Critical School. Such a criticism should be based (as Marx has pointed out) upon "the dialectical movement of reality and truth" (Lefebvre, 1969: 3). The truth for Marx, as well as the Critical School, is inseparable from a given society's actual conduct of life. The critique of present reality aims to show the possibilities of overcoming and going beyond the present situation, the mere process which is inherent in history. The critique of present conditions will give way to the necessity of change. Such a necessity will be a new reality which aims at negation of existing reality. The present reality, in light of this critique, will lose its grounds and will be proven as a false-reality. According to Critical Theory, the method of overcoming and going beyond the false-reality is a negative dialectic, which is the core of a critical theory of society.

The . alienation of "subjective reason" from "objective reason" and the domination of the former over the latter have blocked the transcendental nature of history. The false reality has been metamorphized by the system of domination as the ultimate reality which remains unchanged. Reason is thus no longer a means of criticizing domination and its legitimizing bases. It is unable to go beyond the existing social constraints in order to observe the present against a possible future.

It should be noted that the ideas of truth and reality and the dialectical movement between them constitute an unsolved problem of Marxism and later of the Critical School. The attempts of Marxists and critical theorists have not solved the problem manifested in the quest for grounding truth and reality. The theory of cognition as a reflection of social existence with its positivistic orientation has failed to present an acceptable ground for reality which man aims to achieve through his "constant and progressive evolution. Man is involved in ...limitless striving for perfection... which intends to make it more similar to reality ..." (Kolakowski, 1969: 39). 


\section{MARCUSE'S AESTHETIC PERSPECTIVE}

Despite the quest for grounding the idea of reality and its transcendental nature, the present situation is, according to Marcuse and other critical theorists, in need of revolutionary change for a better reality in which the environment of freedom will come to exist. For creating such an environment, Marcuse suggests a complementation and enhancement of instrumental rationality with the aesthetic perspective.

For Marcuse, the modern society, by means of technology and science, has gained enormous rational capacities. But such capacities have been negated by the intervention of irrational political systems and therefore cannot contribute to the happiness of mankind. Technology, which is able to emancipate man from an irrational work system, has been used for creating false needs and a great desire for fulfilling those needs. Hence, it has deepened the irrationality of work systems which benefit the status quo.

Rationality is not an absolute, unchanging factor, but relative to the respective historical movement. Historical development and changing reality expose rationality to be still irrational: reason becomes nonsense. Contemporary rationality is also disavowed by the fact that it wants to perpetuate the status quo. It calls theories that contradict the existing universe irrational, while they are the rational ones precisely because they refuse to cooperate with madness (Landmann, 1976: 195).

Under presert circumstances, reason is not. "a critical tribunal" as it is supposed to be, and work is no longer a pathway toward self-realization and emancipation. Reason through the instrumental perspective has enabled the modern society to adopt new styles of life which are based on a higher standard of living and has created more comfort. But man has received this coupled with the high cost of the enormous frustration and imprisonment which has been portrayed in modern life. Consequently, a new approach toward social phenomena should be developed in order to explain the dialectical relationships between man, society, and nature.
The traditional perspectives were not in a position to predict the technological development of our time, the emergence of irrational political systems, and the intervention of these systems in the process of production and in the operation of technological rationality. The domination of technical-administrative systems as a new source of alienation cannot be explained merely by movements of economic exchange. Therefore, a new perspective should be developed in response to the characteristics of contemporary systems of domination. But what is to be done?

Marcuse argues that:

... strengthening any of the partial rationalities of the present system can only contribute further to the irrationality of the whole. It would be an intensification of repression and destruction, which are the work of this false rationality. Therefore, mere reforms, improvements in detail, are of no help, but, on the contrary, serve the bad whole. What is necessary is a revolutionary change of the system itself, a "reversal of the trend." But that means a break with the prevalent technological rationality

(Landmann, 1976: 195).

In order to make the present situation rational, Marcuse deeply believes that a revolutionary change is necessary, and Critical Theory serves as a guideline for such a change. The central point of revolutionary change is the relationship between man and nature, a relationship which under the present circumstances is destructive and a major source of frustration. In reference to the necessity of a revolutionary change within the system and the relationship of man to nature, Marcuse has presented his aesthetic perspective, which aims at the potential emancipation of man.

In Counterrevolution and Revolt, he has suggested that:

... if the instrumental perspective-nature as perceived according to the form of technical control-is taken as the only guiding principle of human action, its objective (the satisfaction of needs) will inevitably be thwarted, owing to distortions in the formulation of needs under these circumstances; the aesthetic perspective must 
complement and enhance, not seek to repeal, the instrumental one in order to realize the full potentialities of nature...(Leiss, 1975: 166).

$\mathrm{He}$ argues that the aesthetic perspective would be able to translate "subjective sensibility into objective form" (Marcuse, 1969), and thus nature would not be approached as a mere object outside man and ready for exploitation.

In short, Marcuse has indicated the necessity of a revolutionary change which aims to transform the irrationality of modern time. He quests for a synthesis between subjective and objective approaches toward nature which will create a new possibility to communicate with nature. 'The term 'aesthetic,' in its dual connotation of 'pertaining to the senses' and 'pertaining to art,' may serve to designate the quality of the productive-creative process in an environment of freedom" (Marcuse, 1969: 32).

Although Marcuse believes that a revolutionary change within the system of instrumental rationality is necessary, he nevertheless rejects the usefulness of any reform or even detailed improvements. Furthermore, in his aesthetic perspective he does not believe that instrumental rationality should be repealed, but rather that it should be enhanced and complemented. This is precisely, in my opinion, the contradiction referred to above. For a revolutionary change is a structural change, a destruction of the present system. When a system faces a revolutionary change, there is no guarantee that any part of the system will remain unchanged. Of course, this does not mean that everything will change, but rather that we do not know which part will change and which will not. Marcuse himself agrees with this point. In one of his interviews, Revolution over Reform, he correctly has emphasized that history is not an insurance corporation to guarantee things. This is precisely the contradiction I am referring to here.

Marcuse believes in the necessity of revolutionary change, but at the same time he does not like to see the abolition of technological progress which is based upon instrumental rationality. His aesthetic perspective does not aim to replace instrumental rationality. It is only an approach which gives a subjective meaning to nature and creates a rational end for instrumental rationality. From Marcuse's point of view, it is a combination of the aesthetic and the instrumental perspectives which will create a revolutionary change within the system.

But Marcuse has never indicated the conditions under which the aesthetic perspective will become an acceptable attitude toward nature, or how this perspective, among all possibilities, will be chosen. Moreover, he has never explained the possible confrontation between the existing system of domination and his approach which aims at the negation of this system. Today we are witnessing the establishment of many national and international organizations which deal with different issues regarding the protection of nature. Is this a process of institutionalizing an aesthetic perspective?

In spite of these problems, one thing is very clear: Marcuse does not reject the technological progresses of our time, nor does he desire their abolition.

The progressive reduction of physical labor power in the production process (the process of material production) and its replacement to an increasing degree by mental labor concentrate socially necessary labor in the class of technicians, scientitists, engineers, etc. ... This suggests possible liberation from alienated labor (Marcuse, 1970: 66).

In the preceding passage, which sounds very Saint-Simonian, Marcuse has recognized the potentialities of the present system for change. But what has blocked the realization of these potentialities is the intervention of irrational political systems in the process of total rationality. Moreover, the aesthetic perspective will never come to exist unless the immediate necessities of man are fulfilled. It is childish to believe that the workers, in spite of the existence of an industrial reserve army, will go on strike whenever their company wants to carry out a project which is hostile to nature. For the same reason, it is also childish to believe that a man who is hungry will not destroy nature because of his sense of beauty. 
Mid-American Review of Sociology

The fulfillment of man's needs and the abolition of poverty cannot be attained unless the present system of social hierarchy undergoes thorough revolutionary changes. And if a revolutionary change comes to exist, no one will be able to predict the necessity of an aesthetic perspective after the revolution.

\section{REFERENCES}

Habermas, Jurgen

1970 Toward a Rational Society, Beacon Press: Boston.

Horkheimer, Max

1974 Eclipse of Reason, The Seabury Press: New York.

Kolakowski, Leszek

1968 Toward a Marxist Humanism, Essays on the Left Today, Tr. by Jane Zielonko Peel, Grove Press: New York.

Landmann, Michael

1976 Critiques of Reason from Max Weber to Ernst Bloch, Telos, No. 29, Fall, 187-198.

Lefebvre, Henri

1969 The Sociology of Marx, Vintage Books: New York.

Leiss, William

1975 The Problem of Man and Nature in the Work of the Frankfurt School, Philosophy of Social Science, No. 5:163-172.

Marcuse, Herbert

1972 An Essay on Liberation, Pelican Book: London

1970 Five Lectures, Beacon Press: Boston.

1968

Negations, Essays in Critical Theory, Beacon Press: Boston.

\section{CULT AND SPORT: THE CASE OF BIG RED}

Michael Stein

University of Nebraska-Lincoln

Mid-American Review of Sociology, 1977, Vol. 2, No. 2: 29-42

This paper explores the importance of sport in our society. Several metaphors for sports are presented, including the military and religion. It is argued that for some fans, sport takes on the quality of a secular religion which serves to offer continuity in life, an institutionalized agency for catharsis, a transcendent experience giving followers an escape from the mundane, and a sense of belonging. Using football at the University of Nebraska as an example, empirical support is given for the notion of sport as civil religion.

Though it is certainly conceivable that there are countless persons for whom the name Nebraska elicits absolutely no associations, it is more doubtful that anyone who has heard of the state is not aware of "Big Red" football: the only game in town. It is an activity of sufficient impact to have attracted the attention of television (a special), magazines (Sports Illustrated, National Geographic), and has been noted by "legitimate" authors (e.g., James Michener). It is also felt to be worthy of attention by sociologists. The theoretical frame of this paper revolves around the concept of cult. That is, the "complex of gesture, word and symbolic vehicle which is the central role of this phenomenon ..." (O'Dea, 1966:p. 39). Further, the cultic act "is a social or congregational act in which the group re-enacts its relationship to sacred objects.... and in so doing reinforces its own values" (O'Dea 1966:p. 40).

As Klapp (1964) has suggested, cults may take on a variety of interests and forms including that of recreation. Certainly, sports in general, football in particular, and University of Nebraska football specifically, can rest comfortably under the rubric of a "recreational" cult. It is hoped, however, that this paper will be suggestive of more than mere recreation. ${ }^{1}$ Of course tradition 